Article

\title{
Nutraceutical Uses of Traditional Leafy Vegetables and Transmission of Local Knowledge from Parents to Children in Southern Benin
}

\author{
Amandine D. M. Akakpo and Enoch G. Achigan-Dako *(1) \\ Laboratory of Genetics, Horticulture \& Seed Science, Faculty of Agronomic Sciences, \\ University of Abomey-Calavi, Abomey-Calavi 01BP526, Benin; amandineakakpo@gmail.com \\ * Correspondence: enoch.achigandako@uac.bj
}

Received: 28 October 2019; Accepted: 16 November 2019; Published: 26 November 2019

\begin{abstract}
This study assessed differences on the uses and transmission of traditional knowledge (TK) about three traditional leafy vegetables (Crassocephalum crepidioides (Juss. ex Jacq.) S. Moor, Launaea taraxacifolia (Willd.) Amin ex C. Jeffrey, and Vernonia amygdalina Del.) of the Asteraceae family over two generations in three villages: Adjohoun, Dangbo, and Pobè (southern Benin). Individual semi-structured ethnobotanical interviews of 360 respondents were conducted in the villages with young girls, boys, and their two parents. The relative frequency of citation, use value, and Jaccard similarity index were used for data analyses. Vernonia amygdalina was the most commonly known and used vegetable in all villages, while L. taraxacifolia was confined to Pobè. Factors such as village of survey, generation, and gender affected the use value of the species, but the patterns of recognition and cultivation were species-specific. Leaves were the most used plant part. Traditional knowledge was largely acquired from parents (90\% of citation), and both mothers and fathers transmitted a similar amount of knowledge to their progenies. The knowledge on V. amygdalina was transmitted to a larger scale than knowledge of C. crepidioides and L. taraxacifolia. Irrespective of the species, transmission of TK was higher in Pobè. Gender and generation knowledge dynamic hypothesis is species-specific. TK transmission was species-specific too and may be linked to the local importance and use of those resources. These findings will inform strategies and programs for the sustainable use and conservation of leafy vegetables in local communities and national research and development institutions.
\end{abstract}

Keywords: Crassocephalum crepidioides; ethnobotany; generations; knowledge dynamics; Launaea taraxacifolia; use value; Vernonia amygdalina

\section{Introduction}

Nutraceutical plants loosely allude to species that are used as food or parts of food, and provide medicinal or health benefits-including the prevention and treatment of diseases-based on the perceived health properties of those plants [1]. For instance, several vegetables [2-4] and aromatic plants [5] were recognized as nutraceutical crops and are actively sought out for direct consumption or to be added to meals for their therapeutic or nutrient-rich properties. Those species exhibit specific bioactive compounds that can be used to target a range of diseases. In addition, they contain valuable nutritive elements, such as vitamins, minerals, essential oils, and antioxidants, that play a vital role in healthcare while serving as foods [6]. Recent ethnobotanical studies revealed that vegetable plants are by-and-large consumed by local people in Africa [3,7,8]. In Benin, 245 species belonging to 62 families are consumed as traditional vegetables. Among them, Asteraceae have the widest diversity with 29 species $[9,10]$. In addition, 41 species, including 13 leafy vegetables, have been listed as neglected and underutilized among which Crassocephalum crepidioides e (Voucher ID: Ganvié: Zon 369 
at Benin National Herbarium), Launaea taraxacifolia (Voucher ID: Grand-Popo: Lisowski 0-1141 at Benin National Herbarium), and Vernonia amygdalina (Voucher ID: Massi: Ayichédéhou 434 at Benin National Herbarium). These vegetables are currently among the top ten most consumed leafy vegetables in local communities [11], and exhibit high nutrient content (Table 1), but are neglected by research and development organizations. Moreover, they have difficult sexual reproduction and seeds are scarcely conserved in any national or international germplasms. In southern Benin, C. crepidioides is considered to be on the decline and among the most endangered wild edible plants [12] similarly to L. taraxacifolia [13]. These species are also exploited in traditional healthcare systems, but have been less explicitly documented with respect to their nutraceutical uses.

The knowledge of use value of the three vegetables is relevant not only for economic promotion, but more importantly they are element of the local people's culture which unfortunately is eroded through globalization and westernization $[3,14,15]$ while questions arose about how social dynamics and human traits affect plant selection $[3,16,17]$.

The transmission of traditional knowledge across generations has received increasing interest given the ongoing adverse effects in rural areas, whereby young people are increasingly disinterested in traditional or rural beliefs and life styles $[14,15,18]$. While this issue has been central in conservation biology and the management of plant genetic resources and agrobiodiversity $[14,15,18]$, there are only fewer case studies in West African regions, despite their instrumental importance. Cultural knowledge transmission can occur between individuals of different generations. However, it most often occurs within genealogy (vertical transmission), as is the case from parent to child [19]. Indeed, parents, share their context with their children, and hence play a crucial role in transmitting knowledge in early life [20]. It may also occur between individuals of the same generation, even with different genealogy. However, vertical transmission i.e., across generations, in particular from parents to children, has been found to be highly conservative [14].

This study was therefore conducted to address the following questions: (i) what traditional knowledge is held on the uses of C. crepidioides, L. taraxacifolia, and V. amygdalina, three leafy vegetables of the Asteraceae family? (ii) How does this knowledge change across villages, age groups, and species? (iii) How does the knowledge change across generations, in particular, from parents to their children?

There are several evidences that the use of species varies according to informants' age and gender [21,22]. At the same time, other evidences indicated a neutral relationship [23], suggesting a context-specific relationship [24]. As a result, many recent studies have advocated for species-specific analyses for optimal science-based decision making and policies [24]. In addition, not all species have the same importance for local people, some are more important than others and are therefore the subject of special attention [25]. Among the three species, V. amygdalina is the most common in both rural and urban areas. The other two species are relatively less common [7]. Therefore, we predict to detect a significant gender and age relationship across localities for these two species and a neutral relationship for $V$. amygdalina. In addition, the transmission of local knowledge may depend on the importance of the species. The more a species is important, the more people hold and share knowledge on its uses. As a result, we hypothesized that the transmission of local knowledge from parents to children is species-specific. In particular, we predict to detect better knowledge transmission for V. amygdalina, while a relatively lower knowledge transmission for the other two species may prevail. 
Table 1. Nutrient content of Vernonia amygdalina, Launaea taraxacifolia, and Crassocephalum crepidioides, three leafy vegetables consumed in southern Benin (values are collated from Yang and Keding [4]; Denton [26]; Stadlmayr et al. [27]; Adebisi [28]; Fomum [29]).

\begin{tabular}{cccc}
\hline Nutrients & V. amygdalina & L. taraxacifolia & C. crepidioides \\
\hline Energy (Kcal) & $52-62$ & 44 & 64 \\
Water (g) & 82.6 & 84.3 & 79.9 \\
Protein (g) & 5.2 & 3.2 & 3.2 \\
Fat (g) & 0.4 & 0.8 & 0.7 \\
Carbohydrate (g) & $8.5-10$ & 8.3 & 14.0 \\
Fiber (g) & 1.5 & 2 & 1.9 \\
Ash (g) & 1.7 & - & - \\
Ca (mg) & 145 & 326 & 260 \\
Fe (mg) & 5.0 & - & - \\
P (mg) & 67.0 & 58 & 52 \\
Vit C (mg) & 51 & - & - \\
\hline
\end{tabular}

\section{Materials and Methods}

The study was carried out in three villages of southern Benin with different sociolinguistic groups where the three species were reported [30]. We considered sociolinguistic group as "a group in which a member inherits a common language of communication and shares social attributes such as customs, history, and food habits" [9]. Villages included Adjohoun, Dangbo, and Pobè (Figure 1). The district of Adjohoun is located in the Department of Ouémé, $32 \mathrm{~km}$ north of Porto-Novo. Its total area is nearly $308 \mathrm{~km}^{2}$. Its population is about 74,956 inhabitants [31]. It is composed of $48 \%$ men and about $52 \%$ women. Adjohoun is mainly rural and more than $80 \%$ of the active population is employed in agriculture. The district is mainly populated by the Wémè sociolinguistic group and to a lesser extent by Goun and Yoruba. The district of Dangbo is also located in the Department of Ouémé and covers about $149 \mathrm{~km}^{2}$ with a population size of about 95,908 [31], of which $49 \%$ are men and $51 \%$ are women. The main sociolinguistic group is Aïzo. The third district is Pobè, located in the Department of Plateau. It covers about $400 \mathrm{~km}^{2}$. The population of Pobè is around 123,740 inhabitants and composed of $48 \%$ men and $52 \%$ women. The main sociolinguistic groups is Holly with a minority of Nagot people [32]. All three sociolinguistic groups belong to the 'Kwa' linguistic categories. However, Aïzo and Wémè belong to the 'gbe' subcategory dominated by the Fon/Adja group, while Holly belongs to the 'ede' subcategory dominated by the Yoruba linguistic group [32]. There are differences among sociolinguistic groups and these are related to customs and beliefs, traditional religions, and practices. Communities sharing the same cultural background are likely to have convergent patterns of plant knowledge and use [33], with the exceptions that people of the same sociocultural background living in contrasting phytogeographical areas may also have different plant knowledge [9].

The three municipalities are under a tropical humid climate. Two dry seasons (mid-November to mid-March and mid-July to mid-September) that alternate with two rainy seasons (mid-March to mid-July and mid-September to mid-November). The native vegetation is composed of fallows and small semi-deciduous forest patches often of less than 5 ha, most of which are sacred groves. There are also some swamp forests especially along the Ouémé valley. 

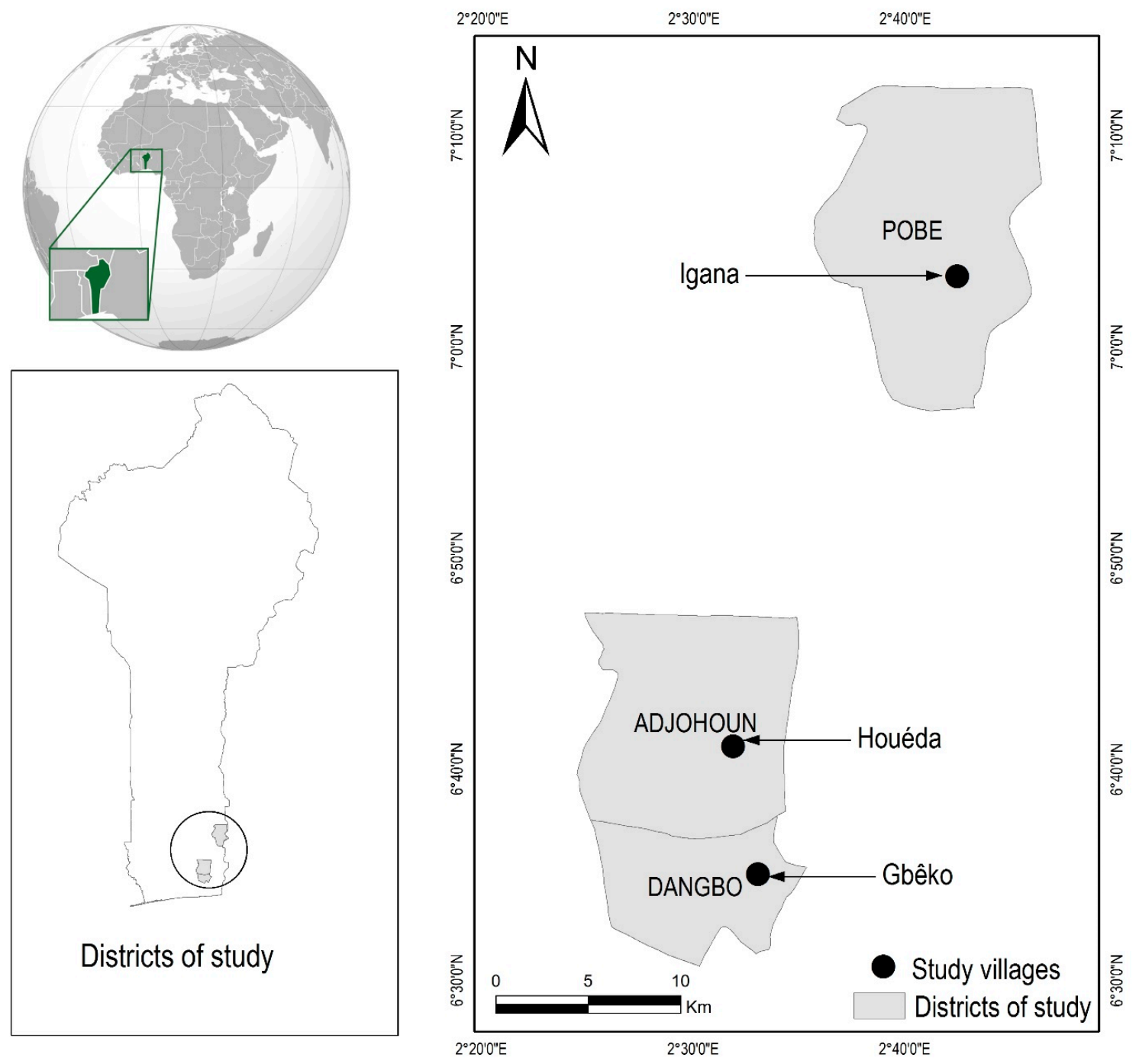

Figure 1. Map showing the municipalities and the villages where the study was carried out.

The objective of the study was first explained to village authorities and also to each of the informants to have their consent for participation prior to interviews. Only individuals that consented to participate in the study were considered. Forty young people aged $15-18$ years ( 20 girls and 20 boys) and their two parents (fathers and mothers) were randomly selected in each village for a total of 120 informants per village, totalling 360 informants for the whole study. The random selection was implemented using the table of random numbers applied to a list of target young people previously established for each village. Young respondents with a single parent were not considered in the sample. The study was conducted in the village of Gbéko (in Dangbo) dominated by the Aïzo sociolinguistic group, the village of Houèda (in Adjohoun) dominated by the Wémè sociolinguistic group, and the village of Igana (in Pobè) dominated by the Holly sociolinguistic group (Table 2). These communities were selected based on previous reports on their distribution [30,32]. In addition, a pilot survey was carried out in each community to confirm the production of at least one of the three traditional leafy vegetables targeted and the good representation of the different sociolinguistic groups. Data were collected through individual interviews with the assistance of experienced local translators that were previously trained. Primary data included: (i) sociodemographic data, (ii) recognition and cultivation of the three leafy vegetable species, (iii) knowledge on the uses of the three species, and (iv) sources of knowledge held by the informants. 
Table 2. Sociodemographic characteristics of informants (village, age, gender, and sociolinguistic group), number of informants surveyed, and their instruction levels. ${ }^{\dagger}$ mean (standard error).

\begin{tabular}{|c|c|c|c|c|c|c|c|c|c|c|c|c|}
\hline \multirow{2}{*}{ Villages } & \multirow{2}{*}{$\begin{array}{c}\text { Age } \\
\text { Categories }\end{array}$} & \multirow{2}{*}{ Gender } & \multirow{2}{*}{ Number } & \multirow{2}{*}{ Age (years) ${ }^{\dagger}$} & \multicolumn{4}{|c|}{ Sociolinguistic Groups (\%) } & \multicolumn{4}{|c|}{ Instruction Levels } \\
\hline & & & & & Wémè & Ä̈zo & Goun & Holly & Illiterate & Primary & Secondary & University \\
\hline \multirow{4}{*}{ Adjohoun } & \multirow{2}{*}{ Parent } & Men & 40 & $48.05(1.94)$ & 87.5 & 0.0 & 12.5 & 0.0 & 47.5 & 40.0 & 7.5 & 5.0 \\
\hline & & Women & 40 & $39.95(1.04)$ & 85.0 & 0.0 & 12.5 & 2.5 & 75.0 & 25.0 & 0.0 & 0.0 \\
\hline & \multirow{2}{*}{ Child } & Boys & 20 & $16.40(0.27)$ & 85.0 & 0.0 & 15.0 & 0.0 & 0.0 & 35.0 & 65.0 & 0.0 \\
\hline & & Girls & 20 & $16.30(0.34)$ & 90.0 & 0.0 & 10.0 & 0.0 & 0.0 & 15.0 & 85.0 & 0.0 \\
\hline \multirow{4}{*}{ Dangbo } & \multirow{2}{*}{ Parent } & Men & 40 & $48.08(1.78)$ & 0.0 & 100.0 & 0.0 & 0.0 & 40.0 & 40.0 & 17.5 & 2.5 \\
\hline & & Women & 40 & $44.95(1.26)$ & 7.5 & 92.5 & 0.0 & 0.0 & 75.0 & 22.5 & 2.5 & 0.0 \\
\hline & \multirow{2}{*}{ Child } & Boys & 20 & $16.45(0.23)$ & 0.0 & 100.0 & 0.0 & 0.0 & 0.0 & 0.0 & 100.0 & 0.0 \\
\hline & & Girls & 20 & $16.80(0.29)$ & 0.0 & 100.0 & 0.0 & 0.0 & 25.0 & 20.0 & 55.0 & 0.0 \\
\hline \multirow{4}{*}{ Pobè } & \multirow{2}{*}{ Parent } & Men & 40 & $46.11(1.35)$ & 0.0 & 0.0 & 0.0 & 100.0 & 80.0 & 7.5 & 12.5 & 0.0 \\
\hline & & Women & 40 & $42.44(1.36)$ & 0.0 & 0.0 & 0.0 & 100.0 & 95.0 & 2.5 & 2.5 & 0.0 \\
\hline & \multirow{2}{*}{ Child } & Boys & 20 & $15.62(0.15)$ & 0.0 & 0.0 & 0.0 & 100.0 & 0.0 & 14.29 & 85.71 & 0.0 \\
\hline & & Girls & 20 & $16.26(0.30)$ & 0.0 & 0.0 & 0.0 & 100.0 & 5.26 & 10.53 & 84.21 & 0.0 \\
\hline
\end{tabular}


Descriptive statistics based on the relative frequency of citation (RFC, \%) was used to describe the pattern of recognition and cultivation of the target traditional leafy vegetables.

The analysis of the knowledge of the uses of the vegetables was based on four ethnobotanical indices. Total use value $\left(\mathrm{UV}_{\text {Total }}\right)$, food use value $\left(\mathrm{UV}_{\mathrm{Food}}\right)$, medicinal use value ( $\left.\mathrm{UV}_{\text {Medicinal }}\right)$, plant part use value (PPUV), and the relative frequency of citation (RFC) of each specific use were reported. The use value was adapted from Etongo et al. [34], while PPUV was adapted from Gomez-Beloz [35] and RFC was similar to the fidelity level of Friedman et al. [36].

The total use value $\left(\mathrm{UV}_{\text {Total }}\right)$ of the species $s$ is the average total number of uses reported by all informants for that species, which is the sum of the average number of uses reported in the food use category $\left(\mathrm{UV}_{\mathrm{Food}}\right)$ and the average number of uses reported in the medicinal use category ( $\left.\mathrm{UV}_{\text {Medicinal }}\right)$ as described in Equations (1) and (2).

$$
\begin{gathered}
U V_{\text {Total }}=U V_{\text {Food }}+U V_{\text {Medicinal }} \\
U V_{\text {Total }}=\sum_{i=1}^{n} \frac{U R_{\text {Food }_{i}}}{n}+\sum_{i=1}^{n} \frac{U R_{\text {Medicinal }_{i}}}{n}
\end{gathered}
$$

where $\mathrm{UR}_{\mathrm{Food}} \mathrm{i}$ is the total number of food uses reported for species $s$ by informant $i$, $\mathrm{UR}_{\text {Medicinal } \mathrm{i}}$ is the total number of medicinal uses reported for species $s$ by informant $I$, and $\mathrm{n}$ is the number of informants in the sociocultural category considered for computation.

To test whether the use value of a species correlated with generation (children versus parents), gender (men and women) and village (Igana, Houéda, Gbéko), a Poisson generalized linear model (GLM) was performed with generation, gender, and village as predictors and use values as response variables. The full model (i.e., with all possible interactions) was first established. Then, the most parsimonious model (i.e., the one with the minimum significant predictors) was searched using backward elimination based on likelihood ratio tests.

The plant part use value (PPUV) measures the use value of each plant part for each species. It is the average number of uses reported for that plant part for a given species. For a plant part $k$ of a species $s, \operatorname{PPUV}_{\mathrm{k}, \mathrm{s}}$ was computed as follows:

$$
\operatorname{PPUV}_{k, s}=\sum_{i=1}^{n} \frac{U R_{k, s, i}}{n}
$$

where $\mathrm{UR}_{\mathrm{k}, \mathrm{s}, \mathrm{i}}$ is the number of reported uses by the informant $i$ for the plant part $k$ of the species $s$.

PPUV was used to identify the most used plant part for each species. To test whether the PPUV depends on the plant part, a Poisson GLM was also used.

The relative frequency of citation (RFC) is a measure of how much informants agree on a specific use (i.e., the consensus of informants on that use or knowledge). For each specific use $m$ of each species $s$, RFC $\left(\mathrm{RFC}_{\mathrm{ps}}\right)$ was computed as the number of informants who cited the specific use $m\left(\mathrm{n}_{\mathrm{m}, \mathrm{s}}\right)$ divided by the total number of informants for the species $s\left(\mathrm{~N}_{\mathrm{s}}\right)[36]$.

$$
R F C_{m, s}(\%)=\frac{n_{m, s}}{N_{s}} \times 100
$$

The transmission of local knowledge from parents to child was assessed by two means. First, frequency analysis was used to describe the sources of knowledge (from who the knowledge was obtained). Second, the Jaccard similarity index was calculated to quantify the degree of similarity in knowledge held by children (distinguishing boys and girls) with that of their parents (distinguishing fathers and mothers) as indicated in Equation (5).

$$
\text { Jaccard similarity }=\frac{a}{a+b+c} \times 100
$$


where $\mathrm{a}$ is the number of uses common to a child (boy or girl, taken separately) and the parent (mother or father, taken separately), $\mathrm{b}$ is the number of uses reported only by the parent, and $\mathrm{c}$ is the number of uses reported only by the child.

Two-sample T-tests were used to compare child/parent knowledge similarities for each species in each village. An analysis of variance (ANOVA) on log-transformed similarities (to meet ANOVA assumptions of normality and homoscedasticity) was performed to test whether the degree of shared knowledge varied with the gender of the child (boy vs girl), gender of parent (mother $v s$ father), and village. The initial full model including main and interaction effects was simplified to minimum adequate using a stepwise selection. All statistical analyses were performed in R version 3.3.2 [37].

\section{Results}

\subsection{Sociodemographic Characteristics of Informants}

Mothers were generally younger ( $39.95 \pm 1.04$ to $44.95 \pm 1.26$ years old) than fathers (46.11 \pm 1.35 to $48.08 \pm 1.78$ years old). Girls and boys had similar ages, $15.62 \pm 0.15$ years and $16.80 \pm 0.29$ years, respectively. In addition, most of the children were educated, in contrast to their parents $(100 \%, 87.5 \%$, and $97.4 \%$ educated children against $38.8 \%, 42.5 \%$, and $12.5 \%$ educated parents in Adjohoun, Dangbo, and Pobè, respectively) (Table 2). Most of the children had a secondary school level of education $(\geq 55 \%$ ) (Table 2). The illiteracy rate among parents was higher in Pobè than in the other two villages (Table 2). Irrespective of the village, illiteracy rate was higher $(\geq 75 \%)$ among mothers than fathers (Table 2). Agriculture and retailing were the main activities of the parents and occupied $46 \%$ and $14 \%$ of the respondents, respectively. Children mostly went to school (greater than $60 \%$ ).

\subsection{Pattern of Recognition and Cultivation of Traditional Leafy Vegetables}

The recognition and cultivation patterns exhibited different topology and changed mainly across villages and species (Figure 2). Overall, recognition and cultivation perception of the three leafy vegetables changed among villages, species, and informant generations. Vernonia amygdalina was the most recognized and cultivated, while $L$. taraxacifolia was the least recognized and cultivated.

We observed that $V$. amygdalina was by-and-large recognized by children and parents in all three villages irrespective of the gender and generation. C. crepidioides and L. taraxacifolia were recognized by children and parents only in Pobè (100\% relative frequency of citation), a Holly sociolinguistic community. In Dangbo (populated by Wémè), parents showed a citation frequency higher than $80 \%$ for L. taraxacifolia and C. crepidioides; about 30\% of children informants only cited the two species in that village. In Adjohoun (Aïzo community), the citation frequencies were even lower for those two species for both parents and children $(<50 \%$ and $<20 \%$, respectively) compared with Dangbo and Pobè.

Cultivation citations showed different patterns. Vernonia amygdalina was cultivated in all three villages by both children and parents with no gender difference, though in Pobè the cultivation citation frequencies were lower than that in the other two villages. Crassocephalum crepidioides was cultivated by very few parents in the Aïzo sociolinguistic group in Adjohoun; in Dangbo, it was cultivated by fewer young informants (less than 20\%) and a relatively moderate number of parents (about 50\%). In the Holly community in Pobè, C. crepidioides was cultivated by a higher number of children and parents, irrespective of the gender. Citation frequencies of the cultivation of L. taraxacifolia were overall low in Pobè and nil in the other two villages. 


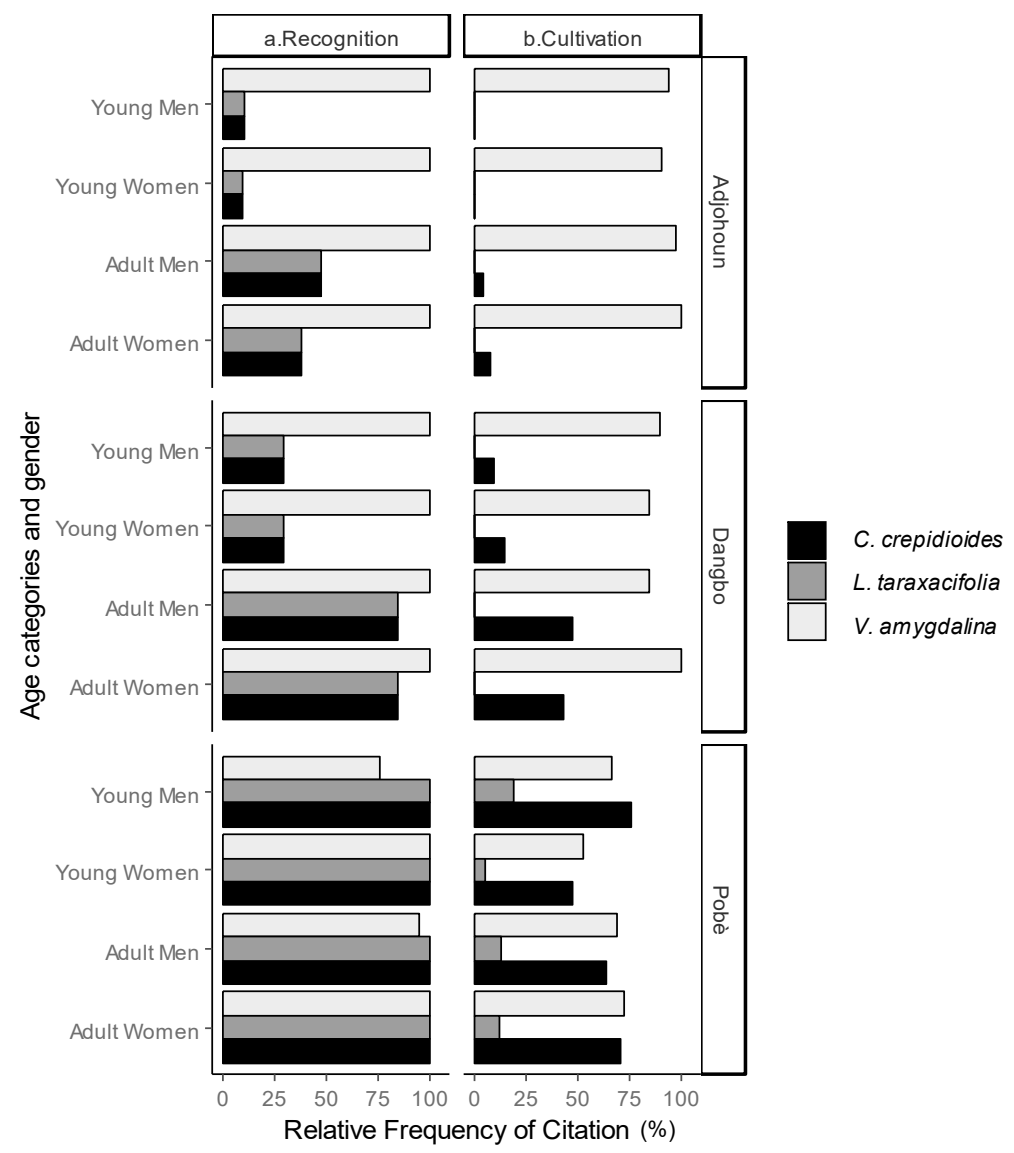

Figure 2. Pattern of recognition and cultivation of C. crepidioides, L. taraxacifolia, and V. amygdalina among informants in Pobè (Holly), Dangbo (Wémè), and Adjohoun (Aïzo).

3.3. Use Value and Diversity of Utilizations in C. crepidioides, V. amygdalina, and L. taraxacifolia

\subsubsection{Use Value of Species Across Generation, Gender, and Village}

\section{- Crassocephalum Crepidioides}

The total use value of $C$. crepidioides was $0.23 \pm 0.05$ in Adjohoun, $0.51 \pm 0.05$ in Dangbo, and $0.91 \pm 0.04$ in Pobè. The total use value of this species was $0.63 \pm 0.04$ for adults, $0.38 \pm 0.05$ for young informants, $0.53 \pm 0.04$ for women, and $0.57 \pm 0.05$ for men. There was no significant relationship between gender and total use value of $C$. crepidioides. However, young informants had a significantly lower use value compared to parents $(p<0.003$, Table 3 , Figure 3$)$. In addition, the total use value of C. crepidioides differed among villages; Pobè had the highest use value $(p<0.001)$, while Dangbo had a non-significantly different use value although higher than the value of Adjohoun. A similar trend was noticed for the food use value (Table 3, Figure 3). The medicinal use value of $C$. crepidioides was higher for men than women (Table 3, Figure 3). Overall, the food use value of $C$. crepidioides outweighed the medicinal use value (up to $96 \%$ of the species total use value).

- Launaea Taraxacifolia

The total use value of L. taraxacifolia differed only among villages, with Pobè having the highest value $(0.48 \pm 0.05$ against $0.06 \pm 0.03$ for Adjohoun and $0.01 \pm 0.01$ for Dangbo) (Figure 3, Table 3). A similar trend was noticed for the food use value. The medicinal use value, however, was similar between a child and parent, and men and women, though women had a relatively higher use value $(0.22 \pm 0.04$ for women against $0.15 \pm 0.03$ for men). The medicinal use value was similar between gender, generation, and villages $(p>0.05)$. Overall, the food use value of L. taraxacifolia also outweighed 
the medicinal use value ( $>89 \%$ of the species total use value) although the latter exhibited more cited specific uses (Table 4).

Table 3. Relationship between total $\left(\mathrm{UV}_{\text {Total }}\right)$, food $\left(\mathrm{UV}_{\text {Food }}\right)$, and medicinal $\left(\mathrm{UV}_{\text {Medicinal }}\right)$ use values and informant gender, generation, and location (village): Summary of Poisson Generalized Linear Models.

\begin{tabular}{|c|c|c|c|c|c|c|c|c|c|}
\hline \multirow{2}{*}{$\begin{array}{c}\text { Terms in the Final } \\
\text { Model }\end{array}$} & \multicolumn{3}{|c|}{$\mathbf{U V}_{\text {Total }}$} & \multicolumn{3}{|c|}{ UV $_{\text {Food }}$} & \multicolumn{3}{|c|}{ UV $_{\text {Medicinal }}$} \\
\hline & est & se & $p$ & est & se & $p$ & est & se & $p$ \\
\hline \multicolumn{10}{|c|}{ C. crepidioides } \\
\hline Gender: women & - & - & - & - & - & - & -1.55 & 0.33 & $<0.001$ \\
\hline Generation: young & -0.25 & 0.08 & 0.003 & -0.24 & 0.09 & 0.007 & - & - & - \\
\hline Village: Dangbo & 0.08 & 0.11 & 0.483 & 0.15 & 0.12 & $<0.001$ & - & - & - \\
\hline Village: Pobè & 0.74 & 0.14 & $<0.001$ & 0.89 & 0.15 & $<0.001$ & - & - & - \\
\hline \multicolumn{10}{|c|}{ L. taraxaciolia } \\
\hline Gender: men & - & - & - & - & - & - & - & - & - \\
\hline Generation: young & - & - & - & - & - & - & - & - & - \\
\hline Village: Dangbo & -3.17 & 1.63 & 0.052 & -1.71 & 0.69 & 0.014 & - & - & - \\
\hline Village: Pobè & 2.30 & 0.87 & 0.008 & -0.61 & 0.51 & 0.229 & - & - & - \\
\hline \multicolumn{10}{|c|}{ V. amygdalina } \\
\hline Gender: women & - & - & - & 0.04 & 0.02 & 0.026 & - & - & - \\
\hline Generation: young & -0.08 & 0.03 & 0.014 & - & - & - & -0.16 & 0.07 & 0.019 \\
\hline Village: Dangbo & -0.09 & 0.04 & 0.034 & -0.03 & 0.02 & 0.277 & -0.24 & 0.09 & 0.009 \\
\hline Village: Pobè & -0.27 & 0.04 & $<0.001$ & -0.07 & 0.02 & 0.004 & -0.56 & 0.08 & $<0.001$ \\
\hline
\end{tabular}

Reference levels: men for gender, adult for generation, and Adjohoun for village; est = estimate, se = standard error, $p=$ probability of the test, - means that the factor was not selected in the parsimonious model.
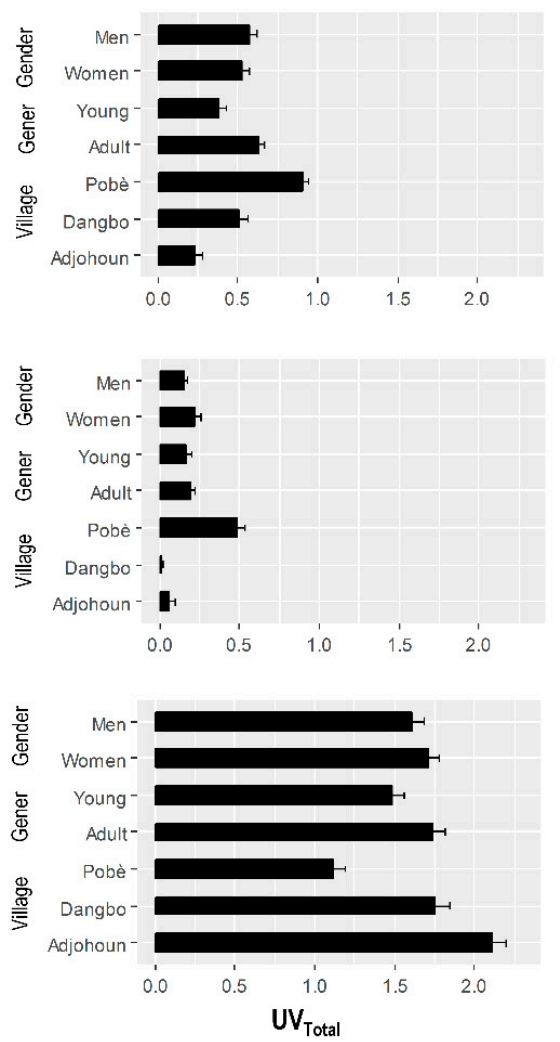
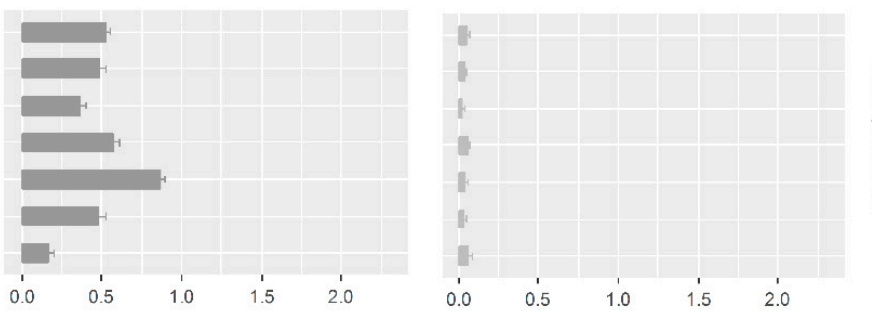

0
$\frac{0}{8}$
$\frac{0}{0}$
$\frac{0}{0}$
$\frac{0}{8}$
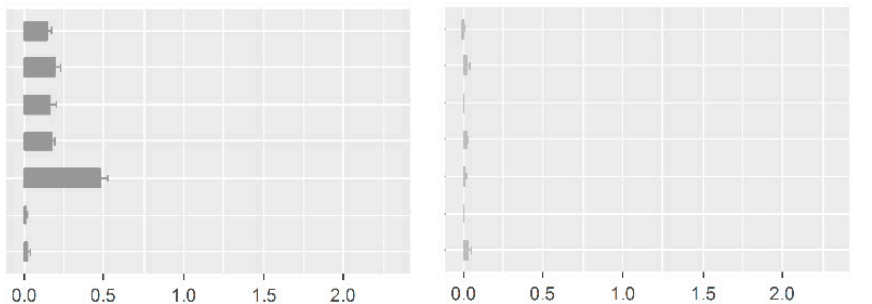

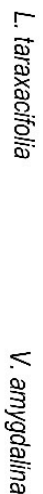
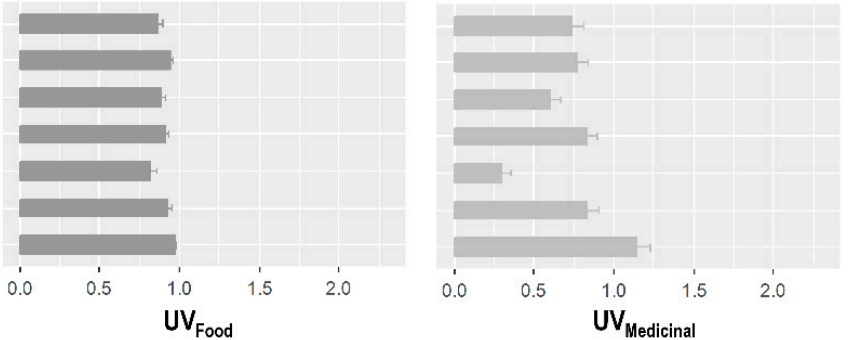

Figure 3. Variation of food, medicinal, and total use values of the three leafy vegetables in relation to location, generation (abbreviated as gener), and gender. Bars represent mean value and the error bars are the corresponding standard errors. 
Table 4. Use categories, description of utilization, and relative frequency of citation (RFC, \%) of three traditional leafy vegetables as reported by informants in Adjohoun, Dangbo, and Pobè.

\begin{tabular}{|c|c|c|c|c|c|c|c|}
\hline \multirow{2}{*}{ Species } & \multirow{2}{*}{ Local Names ${ }^{\dagger}$} & \multirow{2}{*}{ Plant Part } & \multirow{2}{*}{$\begin{array}{c}\text { Use } \\
\text { Categories }\end{array}$} & \multirow{2}{*}{ Description of Food and Medicinal Uses Reported } & \multicolumn{3}{|c|}{ RFC (\%) } \\
\hline & & & & & Adjohoun & Dangbo & Pobè \\
\hline \multirow{9}{*}{ C. crepidioides } & \multirow{9}{*}{$\begin{array}{l}\text { Gbolo (Wémè) } \\
\text { Gbolo/Akogbo } \\
\text { (Aïzo) } \\
\text { Gbolo (Holly) }\end{array}$} & \multirow{9}{*}{ Leaves } & \multirow{2}{*}{ Food } & Consumed as a sauce & 15.83 & 49.17 & 88.33 \\
\hline & & & & Toast of the leaves with seasoning in leaves of Musa spp. L. & 0.83 & 0.00 & 0.00 \\
\hline & & & \multirow{7}{*}{ Medicinal } & Consumed as a sauce to kill intestinal worms & 0.83 & 0.83 & 0.00 \\
\hline & & & & Consumed as a sauce to treat aches & 0.00 & 0.00 & 0.83 \\
\hline & & & & Consumption as a sauce or an infusion in an antibiotic & 1.67 & 1.67 & 0.00 \\
\hline & & & & Eating the leaves daily treats rheumatism & 0.83 & 0.00 & 0.00 \\
\hline & & & & Trituration and consumption of the juice for tonsillitis & 0.83 & 0.00 & 0.00 \\
\hline & & & & Trituration with salt and lemon is used to treat ulcer & 0.00 & 0.83 & 0.00 \\
\hline & & & & Use of an infusion in infants' bath to treat fever & 0.00 & 0.00 & 2.50 \\
\hline \multirow{5}{*}{ L. taraxacifolia } & \multirow{5}{*}{$\begin{array}{l}\text { Awonto (Wémè) } \\
\text { Awonto (Aïzo) } \\
\text { Efognanri/Gnanri } \\
\text { (Holly) }\end{array}$} & \multirow{4}{*}{ Leaves } & Food & Consumed as a sauce & 1.67 & 0.83 & 47.50 \\
\hline & & & \multirow{3}{*}{ Medicinal } & Trituration added with palm oil to rub the body to treat fever & 0.83 & 0.00 & 0.00 \\
\hline & & & & Trituration extract on wound to induce healing and reduce scarring & 0.83 & 0.00 & 0.00 \\
\hline & & & & Trituration extract as a drink for fever & 0.00 & 0.00 & 0.83 \\
\hline & & Stem & Medicinal & $\begin{array}{l}\text { Seasoning the stem with salt and leaving it closer to the fire stimulates the } \\
\text { appetite of patients }\end{array}$ & 0.83 & 0.00 & 0.00 \\
\hline \multirow{11}{*}{ V. amygdalina } & \multirow{11}{*}{$\begin{array}{l}\text { Alomangbo } \\
\text { (Wémè) } \\
\text { Aloman (Aïzo) } \\
\text { Eyouro (Holly) }\end{array}$} & \multirow{11}{*}{ Leaves } & Food & Consumed as a sauce & 97.50 & 92.50 & 81.67 \\
\hline & & & \multirow{10}{*}{ Medicinal } & Trituration extract used to treat tooth pains & 0.83 & 0.00 & 0.00 \\
\hline & & & & Trituration extract used to treat burns and snake bites and to induce healing & 2.50 & 0.83 & 0.83 \\
\hline & & & & Trituration added with palm oil to rub the body to treat fever & 25.83 & 18.33 & 0.00 \\
\hline & & & & Trituration extract added to lemon juice and used as a drink to treat fever & 1.67 & 2.50 & 0.83 \\
\hline & & & & Trituration with salt to brush teeth for anorexia & 3.33 & 7.50 & 0.00 \\
\hline & & & & Trituration extract as a drink to treat stomach pains & 15.00 & 4.17 & 2.50 \\
\hline & & & & Trituration extract as a drink to treat ulcer & 0.83 & 0.00 & 0.00 \\
\hline & & & & Trituration extract as a drink to treat fever & 5.83 & 5.83 & 2.50 \\
\hline & & & & Slightly softened leaves with salt to swallow for treating tonsillitis & 1.67 & 3.33 & 0.00 \\
\hline & & & & Brush the teeth with the leaves to treat bad breath & 13.33 & 0.00 & 0.83 \\
\hline
\end{tabular}


Table 4. Cont.

\begin{tabular}{|c|c|c|c|c|c|c|c|}
\hline \multirow{2}{*}{ Species } & \multirow{2}{*}{ Local Names ${ }^{\dagger}$} & \multirow{2}{*}{ Plant Part } & \multirow{2}{*}{$\begin{array}{c}\text { Use } \\
\text { Categories }\end{array}$} & \multirow{2}{*}{ Description of Food and Medicinal Uses Reported } & \multicolumn{3}{|c|}{ RFC (\%) } \\
\hline & & & & & Adjohoun & Dangbo & Pobè \\
\hline \multirow{25}{*}{ V. amygdalina } & \multirow{25}{*}{$\begin{array}{l}\text { Alomangbo } \\
\text { (Wémè) } \\
\text { Aloman (Aïzo) } \\
\text { Eyouro (Holly) }\end{array}$} & \multirow{25}{*}{ Leaves } & \multirow{25}{*}{ Medicinal } & Trituration added with palm oil is used to rub the body to treat measles & 5.83 & 0.00 & 0.00 \\
\hline & & & & Trituration with leaves of Ocimum gratissimum and salt to treat stomach pains & 0.83 & 1.67 & 0.00 \\
\hline & & & & Extract with salt and lemon used as a drink to treat headaches & 0.83 & 0.00 & 0.00 \\
\hline & & & & Extract with salt is used to treat fever & 2.50 & 0.00 & 0.00 \\
\hline & & & & Extract is used to treat measles & 10.83 & 1.67 & 0.00 \\
\hline & & & & Extract is used as a drink to treat chickenpox & 2.50 & 0.83 & 0.00 \\
\hline & & & & Ethanolic extract is given to children to treat chickenpox & 0.83 & 0.83 & 0.00 \\
\hline & & & & Consumption as a sauce for anorexia & 1.67 & 0.00 & 3.33 \\
\hline & & & & Extract is used as a drink to kill worms & 3.33 & 5.83 & 0.00 \\
\hline & & & & $\begin{array}{l}\text { Extract with petroleum and palm oil plus seven or nine pinches of sand and } \\
\text { rub it on children's body to heal fever }\end{array}$ & 0.83 & 0.00 & 0.00 \\
\hline & & & & Extract with lemon juice used to treat stomach aches & 2.50 & 0.00 & 0.00 \\
\hline & & & & $\begin{array}{l}\text { The leaves are wrapped in banana's leaves with a little salt and then heated } \\
\text { in the ash to collect the juice in a spoon that is given to children to treat } \\
\text { horrible stomach aches }\end{array}$ & 0.83 & 0.00 & 0.00 \\
\hline & & & & Extract added with palm oil is used as a drink against vomiting & 0.83 & 1.67 & 0.00 \\
\hline & & & & Extract is used as a drink to treat hypertension & 0.83 & 0.83 & 0.00 \\
\hline & & & & Extract is used as an antibiotic & 0.00 & 0.83 & 0.00 \\
\hline & & & & Macerate and drink it to treat malaria & 0.00 & 1.67 & 0.00 \\
\hline & & & & Triturate + palm oil + "red capsule" for scarring & 0.00 & 0.83 & 0.00 \\
\hline & & & & Eat leaves uncooked to treat mouth wounds & 0.00 & 0.83 & 0.00 \\
\hline & & & & Triturate and drink the juice to treat cough & 0.83 & 0.83 & 3.33 \\
\hline & & & & Triturate the leaves and take the bath with it to treat fever & 0.00 & 1.67 & 0.00 \\
\hline & & & & Triturate and drink the juice to treat scabby penis & 0.00 & 0.83 & 0.00 \\
\hline & & & & Triturate and squeeze the juice in the ears to treat ear aches & 0.00 & 0.83 & 0.00 \\
\hline & & & & Macerate the leaves with immature papaya and drink it to treat malaria & 0.00 & 0.83 & 0.00 \\
\hline & & & & Triturate and drink the juice for treating hemorrhages & 0.00 & 0.83 & 0.00 \\
\hline & & & & Triturate the leaves in the shower water to treat scabies and measles & 0.00 & 0.00 & 1.67 \\
\hline
\end{tabular}


Table 4. Cont

\begin{tabular}{|c|c|c|c|c|c|c|c|}
\hline \multirow{2}{*}{ Species } & \multirow{2}{*}{ Local Names ${ }^{\dagger}$} & \multirow{2}{*}{ Plant Part } & \multirow{2}{*}{$\begin{array}{c}\text { Use } \\
\text { Categories }\end{array}$} & \multirow{2}{*}{ Description of Food and Medicinal Uses Reported } & \multicolumn{3}{|c|}{ RFC (\%) } \\
\hline & & & & & Adjohoun & Dangbo & Pobè \\
\hline \multirow{15}{*}{ V. amygdalina } & \multirow{15}{*}{$\begin{array}{l}\text { Alomangbo } \\
\text { (Wémè) } \\
\text { Aloman (Aïzo) } \\
\text { Eyouro (Holly) }\end{array}$} & \multirow{3}{*}{ Leaves } & \multirow{3}{*}{ Medicinal } & Triturate and drink the juice to treat cold & 0.00 & 0.00 & 2.50 \\
\hline & & & & Triturate and drink the juice to treat allergies & 0.00 & 0.00 & 1.67 \\
\hline & & & & Triturate and drink the juice against vomiting & 0.00 & 1.67 & 2.50 \\
\hline & & \multirow{10}{*}{ Stem } & \multirow{10}{*}{ Medicinal } & Toothbrush for tonsillitis & 1.67 & 0.83 & 0.00 \\
\hline & & & & Remove the first layer and put salt on the stem then brush with it to treat cold & 0.83 & 0.00 & 0.00 \\
\hline & & & & Against anorexia and bad breath & 2.50 & 0.00 & 0.00 \\
\hline & & & & Dry powder is used to treat stomach aches & 0.83 & 0.00 & 0.83 \\
\hline & & & & Sore throat & 0.00 & 0.83 & 0.00 \\
\hline & & & & Stomach aches & 0.00 & 2.50 & 0.00 \\
\hline & & & & Nausea & 0.00 & 1.67 & 0.00 \\
\hline & & & & Snake bites & 0.00 & 0.83 & 0.00 \\
\hline & & & & $\begin{array}{l}\text { Chew stem }+ \text { Aframomum melegueta } \mathrm{K} \text {. Schum. and swallow the juice only to } \\
\text { treat diarrhoea }\end{array}$ & 0.00 & 1.67 & 0.00 \\
\hline & & & & Infusion of stem + Citrus limon (L.) Burm. f. to treat malaria & 0.00 & 0.00 & 0.83 \\
\hline & & \multirow{2}{*}{ Root } & \multirow{2}{*}{ Medicinal } & Cut the root and put it in a bottle with an alcoholic drink to treat cough & 0.83 & 0.00 & 0.00 \\
\hline & & & & Cut the root and put it in a bottle with an alcoholic drink to treat malaria & 0.83 & 0.00 & 0.00 \\
\hline
\end{tabular}

${ }^{\dagger}$ names in parentheses are local languages for the local names. 


\section{- Vernonia amygdalina}

Contrary to the two previous vegetables, the use value of $V$. amygdalina was the lowest in Pobè (1.11 \pm 0.08 use report per informant), while it was higher in Adjohoun ( $2.11 \pm 0.09$ use report per informant). Children also had a significantly lower total use value compared to adults (Table 3, Figure 3). For the food use, the same trend was observed among villages. However, the use value for women $(0.77 \pm 0.06)$ was significantly higher $(p=0.026)$ than that of men $(0.73 \pm 0.07)$. For the medicinal use value, the trend was the same as that observed for the species total use value. The food use value outweighed the medicinal use value (52\% to $79 \%$ of the species total use value) (Table 3).

In summary, V. amygdalina was more used in Adjohoun, but relatively less used in Pobè. Conversely, the use values of $C$. Crepidioides and L. taraxacifolia were higher in Pobè, but relatively lower in Adjohoun and Dangbo (Figure 3).

\subsubsection{Plant Part Use Value (PPUV), Diversity, and Category of Uses}

Leaves and stem were the two plant parts used for either food or traditional medicine. The plant part use value varied greatly among vegetables. Irrespective of the vegetable, leaves had a higher plant part use value. Specifically, V. amygdalina had the highest leaf PPUV (1.59 \pm 0.05$)$, while L. taraxacifolia had the lowest leaf PPUV $(0.18 \pm 0.02)$. The stem of L. taraxacifolia and C. crepidioides were almost not used (PPUV < 0.006). The stem PPUV of V. amygdalina $(0.26 \pm 0.02)$ was six times lower compared to its leaf PPUV $(1.59 \pm 0.05)$.

Table 4 shows the diversity of the specific uses of the species per plant part, the traditional preparation methods, and their relative frequency of citation per study community.

Nine specific uses were mentioned for $C$. crepidioides, five for L. taraxacifolia, and 52 for $V$. amygdalina. The food uses mainly consist of the consumption of the leaves as a sauce. The leaves of $C$. crepidioides were consumed alone, or as a sauce or roasted with seasoning, in a Musa spp L. leaf. The leaves of $L$. taraxacifolia were also consumed alone as a sauce. As for the leaves of $V$. amygdalina, they were consumed either alone or together with other leafy vegetables, such as Amaranthus spp. L., Celosia argentea L. var. argentea, Solanum macrocarpon L., and Ocimum gratissimum L. The leaves were consumed either fresh or dried or powdered in a Solanum lycopersicum L., Arachis hypogaea L., or Elaeis guineensis Jacq. sauce.

Crassocephalum crepidioides was used against seven ailments; L. taraxacifolia was used against four ailments, while $V$. amygdalina was used to treat 48 ailments (Table 4), i.e., approximately seven and twelve times higher than C. crepidioides and L. taraxacifolia, respectively.

Gastric disorders (e.g., constipation, stomach pain, tooth pain, angina, buccal and intestinal pain, nausea, ulcer, vomiting, diarrhea, and bad breath), respiratory disorders (e.g., cough and cold), fevers, malaria, measles, chickenpox, hypertension, scabies, wound healing, scalds, snake bites, and lack of appetite were treated by the leaves of $V$. amygdalina (Table 4). Tiredness, stiffness, rheumatism, fevers, angina, intestinal disorders, and ulcer were treated by the eaves $C$. crepidioides (Table 4 ). The leaves of L. taraxacifolia were used to treat fevers and wound healing (Table 4).

The stems of L. taraxacifolia were used to treat the lack of appetite during illness, while the stems of $V$. amygdalina were used as toothbrushes, but also against ailments such as gastric disorders (stomach pain, angina, nausea, diarrhea, and bad breath), respiratory disorders (cold), lack of appetite, snake bites, and malaria.

These plant parts were often used alone or together with lemon, salt, palm oil, or a plant part of other plant species such as Ocimum gratissimum L. and Carica papaya L. 


\subsection{Transmission of Traditional Knowledge on Target Vegetables}

The knowledge that the informants hold on the uses of selected vegetables was acquired from their parents (usually more than $90 \%$ of informants, Table 5). The other sources (e.g., social network and formal instruction) were negligible (often less than 15\%) (Table 5).

Table 5. Frequency of citation of the sources of knowledge acquisition on the use of three traditional leafy vegetables as reported by informants in Adjohoun, Dangbo, and Pobè.

\begin{tabular}{|c|c|c|c|c|c|c|c|}
\hline \multirow{2}{*}{ Villages } & \multirow{2}{*}{ Generation } & \multirow{2}{*}{ Gender } & \multicolumn{5}{|c|}{ Sources of Knowledge } \\
\hline & & & Parents & Grandparents & Friends & Training & Others \\
\hline \multirow{4}{*}{ Adjohoun } & \multirow{2}{*}{ Adults } & Men & 92.5 & 10.0 & 2.5 & 0.0 & 2.5 \\
\hline & & Women & 65.0 & 5.0 & 12.5 & 5.0 & 12.5 \\
\hline & \multirow{2}{*}{ Child } & Boys & 100.0 & 0.0 & 5.0 & 0.0 & 0.0 \\
\hline & & Girls & 95.0 & 15.0 & 0.0 & 0.0 & 0.0 \\
\hline \multirow{4}{*}{ Dangbo } & \multirow{2}{*}{ Adults } & Men & 95.0 & 97.5 & 0.0 & 0.0 & 0.0 \\
\hline & & Women & 100.0 & 0.0 & 0.0 & 0.0 & 0.0 \\
\hline & \multirow{2}{*}{ Child } & Boys & 100.0 & 0.0 & 0.0 & 0.0 & 0.0 \\
\hline & & Girls & 100.0 & 5.0 & 0.0 & 0.0 & 0.0 \\
\hline \multirow{4}{*}{ Pobè } & \multirow{2}{*}{ Adults } & Men & 100.0 & 17.5 & 12.5 & 0.0 & 0.0 \\
\hline & & Women & 97.5 & 15.0 & 22.5 & 0.0 & 0.0 \\
\hline & \multirow{2}{*}{ Child } & Boys & 100.0 & 14.3 & 14.3 & 0.0 & 0.0 \\
\hline & & Girls & 94.7 & 21.1 & 31.6 & 0.0 & 0.0 \\
\hline
\end{tabular}

Results from the analysis of the knowledge similarity between boys or girls and the two parents (mother and father) based on Jaccard similarity coefficients showed that for $C$. crepidioides and L. taraxacifolia, no significant difference ( $p>0.05$, Figure 4$)$ was detected between the children and the parents' knowledge in any village. For those two leafy vegetables, the knowledge transmitted by mothers was similar to the one transmitted by fathers. Likewise, child knowledge similarity with that of parents did not differ significantly between girls and boys $(p=0.685$ for $C$. crepidioides, $p=0.426$ for L. taraxacifolia) indicating a similar level of knowledge transmission to boys and girls. Differences were only observed among villages. For $C$. crepidioides, child knowledge similarity with that of parents was at least five times higher in Pobè (Jaccard similarity $=0.74 \pm 0.05)$ than in the other villages $(p<0.01)$. There was practically no knowledge of L. taraxacifolia in Adjohoun and Dangbo and no exchange between children and parents. However, a significant difference was observed between boys and girls whose knowledge of L. taraxacifolia was more similar to that of the parents $(0.64 \pm 0.09)$; boys and parents' knowledge similarity was comparatively lower (Jaccard similarity $=0.31 \pm 0.09$, Figure 4). 


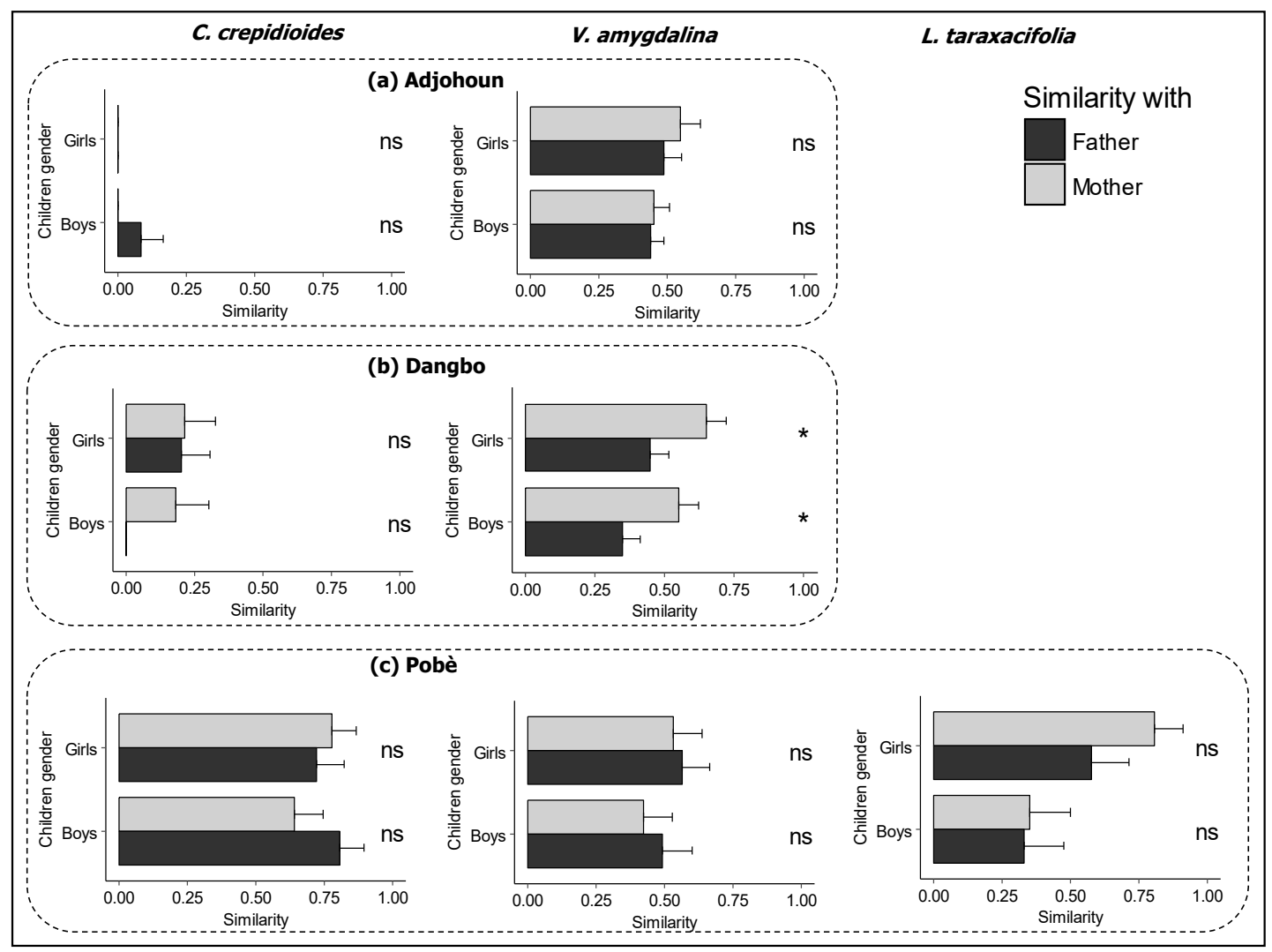

Figure 4. Boys and girls related knowledge similarities with parents in Adjohoun, Pobè, and Dangbo (South Benin). The bars represent mean value and the error bars are the corresponding standard errors. Ns and * are statistical significance of the two-sample t-test comparing children's knowledge similarity with fathers and mothers' knowledge.

For V. amygdalina, we observed a significant difference $(p<0.05)$ between the Jaccard similarity index of children's knowledge and that of fathers' and mothers' in Dangbo (Figure 4). In that village, boys and girls hold a different amount of knowledge with that of their parents (mothers and fathers, separately).

In Pobè, knowledge transmission on V. amygdalina and C. crepidioides was overall the same for both girls and boys, while it was higher for girls than boys for L. taraxacifolia (Figure 4). Irrespective of the vegetable species, about $50 \%$ of parents' knowledge was transmitted to children (Figure 4 ).

In Adjohoun and Dangbo, differences were more perceptible among species. Our results indicated that knowledge on V. amygdalina was better transmitted (0.45-0.65). No knowledge on L. taraxacifolia was transmitted in our respondents from Adjohoun and Dangbo (Figure 4).

\section{Discussion}

\subsection{Pattern of Recognition and Cultivation of Leafy Vegetables Among Informants: Variation Across Generations, Genders, and Villages}

Our results suggested a differential pattern in the recognition and cultivation of the three leafy vegetables across villages, generation, and gender, as the studied vegetables were more recognized in Pobè than in Dangbo and Adjohoun. This differential pattern could be due to the natural distribution of the species and food habits (the species may occur without being used). All three species were reported in the flora of Benin [30] to occur in the study areas (phytodisctricts of Pobè and Ouèmé). Vernonia amygdalina, the most popular vegetable, has historically been used in all parts of the country [9]. It is also cultivated in home gardens and in urban and peri-urban agriculture. The availability hypothesis, according to which, plants are used because they are more accessible or locally abundant [16,38], 
may explain this pattern of recognition. Vernonia amygdalina as a widely distributed and cultivated vegetable [30], was more familiar to local farmers compared to the other two species. Crassocephalum crepidioides was cultivated by only adults at Adjohoun and Dangbo. Launaea taraxacifolia was cultivated only in Pobè by all categories of informants. A higher proportion of older informants cultivated L. taraxacifolia and C. crepidioides in Dangbo and Adjohoun, while neither age-specific nor gender-specific patterns were observed in Pobè. That finding suggested that older informants had more knowledge on the propagation of L. taraxacifolia and C. crepidioides in Dangbo and Adjohoun, while in Pobè younger and older informants, irrespective of their gender, held similar knowledge on all species.

The observed recognition pattern may also be due to the species status (i.e., wild or cultivated), the ability for propagation, or market opportunities. The informants in Adjohoun ascertained that C. crepidioides is a cultivated or wild species, while informants at Dangbo and Pobè thought that the species is a cultivated vegetable but may also be wild. Launaea taraxacifolia was said to be a wild or cultivated species, but $V$. amygdalina was reported as a cultivated and domesticated species. These results are congruent with several previous studies. Vernonia amygdalina is reported as a cultivated plant species, available in all seasons and the 4th of the top five traditional leafy vegetables of importance in Benin after Solanum macrocarpon, Corchorus olitorius L., and Amaranthus cruentus L. [7]. Both C. crepidioides and L. taraxacifolia are considered wild and available only in the rainy season in contrast to $V$. amygdalina, but undergoing a domestication process which is reported to be at the phase of bringing these species into cultivation $[7,39,40]$.

Therefore, knowledge on species propagation is the primary difficulty for farmers. All informants reported that $V$. amygdalina can be propagated by simple cuttings. The other two species were propagated differently, mainly through seeds. However, according to farmers, the seeds of $C$. crepidioides and L. taraxacifolia are not available for production because seeds drop off at maturity and also cannot be stored for long time as they die quickly. Because informants in the village of Pobè were able to cultivate all species, in particular L. taraxacifolia and C. crepidioides, further research on the reproduction biology of those vegetables will be beneficial. Additional reason explaining the observed patterns in the cultivation of three vegetables may be linked to market opportunities which are closely linked to consumption habits because the choice of species for cultivation is dependent on the availability of sales market, the market value [12], and profitability of the species [3].

\subsection{Use Value and Use Diversity of The Three Leafy Vegetables in Relation to Village, Gender, and Generation}

\subsubsection{Use Value of Study Species: Relationship with Informants' Generation, Gender, and Village}

The fact that the total use value of $V$. amygdalina was higher than that of $C$. crepidioides and L. taraxacifolia is congruent with the availability hypothesis which predicts that plants are more known and used because they are more accessible (including easily cultivable) or locally abundant $[16,38]$. Regarding species-specific patterns, older informants held more knowledge on the uses of V. amygdalina and C. crepidioides than younger ones, informants at Pobè held more knowledge on L. taraxacifolia and C. crepidioides, while informants at Dangbo held more knowledge on $V$. amygdalina. The differences between villages can be explained by the availability hypothesis, but also by the local importance of the species. The fact that older informants knew more than younger ones is congruent with the theory that knowledge accumulation on the uses of plants is a life-long process [41]. Therefore, the longer you live, the more you know. This finding contradicts with our prediction of neutral relationships of gender, age, and village with the use value of V. amygdalina. This finding is certainly due to the fact that older informants held more knowledge on the medicinal uses than younger informants.

By disaggregating the overall use value into food use value and medicinal use value, we found a similar trend as the total use value, except that women knew more than men on the food uses of $V$. amygdalina which is congruent with the labor division in households [42] where women are responsible for food in the study villages. With respect to this assumption, and because men are mostly responsible for health issues in households, one should expect that men hold more knowledge on 
medicinal uses [43], which was only true for C. crepidioides. This may be due to the fact that either the species are not practically used (case of L. taraxacifolia and C. crepidioides) or that the medicinal uses are so common that everyone knows the uses which may be true for $V$. amygdalina.

Finally, more than $90 \%$ of the total use value for L. taraxacifolia and C. crepidioides was due to food uses, while about $60 \%$ of the total use value of $V$. amygdalina was due to food use. Therefore, the nutraceutical value was more tangible for V. amygdalina than the others which were mostly food leafy vegetables. Leaves were the most used and this confirmed that they are all leafy vegetables. However, the stem of V. amygdalina was also used for medicinal purposes and as a toothbrush.

\subsubsection{Diversity of Specific Uses Per Category of Uses in Relationship to Villages}

The number of uses cited by informants was about 10 and 6 times higher for $V$. amygdalina (fifty-two) than for C. crepidioides (nine) and L. taraxacifolia (five), respectively. The relative frequency of citation of the use of leaves for food were higher for all three species indicating a consensus on their use as food. The use of leaves as food was mentioned in several previous studies, including Adjatin, et al. [44], Achigan-Dako et al. [10], and Dairo and Adanlawo [40] for C. crepidioides; Arawande et al. [45] and Adebisi [28] for L. taraxacifolia; and Achigan-Dako et al. [10] for V. amygdalina. The leaves may be consumed alone or seasoned with other food ingredients to increase the taste and flavor. Such ingredients in this study included Musa spp leaf, salt, Citrus limon for C. crepidioides; palm oil, and salt for L. taraxacifolia; and palm oil, salt, and O. gratissimum leaves for V. amygdalina. Vernonia amygdalina was used against a number of health disorders seven and twelve times higher than that of $C$. crepidioides and L. taraxacifolia, respectively. Apart from the uses of $V$. amygdalina against fever in children, stomach pains, anorexia, fever, bad breath, and measles, where the relative frequency of citation was greater than $5 \%$ (5\%-26\%, Table 4$)$, for all other cited health disorders, the RFC was low ( $1 \%-2 \%)$ to very low $(<1 \%)$ indicating a relative lack of consensus on this knowledge.

\subsection{Sources and Transmission of Traditional Knowledge on Leafy Vegetables from Parent to Children: Children Sex-Related Knowledge Similarities}

Traditional knowledge on the traditional leafy vegetables were mostly acquired from parents. Similar results were previously reported in Argentina [15] and Canada [18] and referred to as vertical knowledge transmission [46]. The transmission of traditional plant knowledge begins at an early age, as a family custom, in which women play a predominant role [15].

As predicted, the study revealed that the local knowledge transmission depends on the species, but also on the village. Knowledge transmission was not influenced neither by parent gender nor by the sex of the young for V. amygdalina, certainly because of its availability and commonness. This suggests that the more a species is common and used, the more knowledge people hold on its uses, which are effectively transmitted. Knowledge transmission was, however, higher for girls in the case of L. taraxacifolia, certainly because L. taraxacifolia was mostly used for food and because of labour division most of the knowledge was transmitted to girls by both the parents, but mostly by mothers. In addition, knowledge transmission differed among villages, with higher transmission at Pobè for $C$. crepidioides likely, because it was most used and known there. This can also be a particularity of the "Holly" known for its intense relations with the flora in Benin [47].

\section{Conclusions}

Understanding the dynamics of traditional knowledge (TK) and uses of locally adapted but underutilized species is critical for planning actions relevant for agricultural diversification and conservation of resources. The three studied species are important traditional vegetables, but $V$. amygdalina was the most commonly known and used in all villages, while L. taraxacifolia was confined to the village Pobè. Village, generation, and gender had significant effects on the use value, but the patterns or recognition were globally species-specific. Leaves were the most used plant part confirming the three species as leafy vegetables. The TK was acquired from parents, and both mothers and fathers 
transmitted a similar amount of knowledge to their progenies. The knowledge on V. amygdalina was better transmitted and was followed by C. crepidioides and L. taraxacifolia. We conclude that gender and generation knowledge dynamic hypothesis is species-specific and that TK transmission is also species-specific and may be linked to the local importance and use of resources. Due to their nutraceutical value and short cultivation cycle (tree months for first harvest), we propose to increase the production and utilization of these plants and encourage seed production and distribution. Promoting these species in home, school, or allotment gardening could be a good starting point. National agricultural services in partnerships with research institutions can also work together to develop and popularize the best agronomic practices for these species. For this utilization to be sustainable, research on genetic improvement of the species will be instrumental. Such studies are currently lacking or insufficient.

Author Contributions: Conceptualization, A.D.M.A. and E.G.A.-D.; methodology, AD.M.A. and E.G.A.-D.; software, A.D.M.A; validation, A.D.M.A. and E.G.A.-D.; formal analysis, A.D.M.A. and E.G.A.-D.; investigation, A.D.M.A. and E.G.A.-D.; resources, E.G.A.-D.; data curation, A.D.M.A; writing-A.D.M.A.; writing-review and editing, A.D.M.A. and E.G.A.-D.; visualization, A.D.M.A; supervision, E.G.A.-D.; project administration, E.G.A.-D.; funding acquisition, E.G.A.-D.

Funding: This work was funded by the Laboratory of Genetics, Horticulture, and Seed Science (GBioS).

Acknowledgments: Authors are grateful to the local communities of Igana (Pobè), Houèda (Adjohoun), and Gbéko (Dangbo) for having shared their knowledge. We are also grateful to Djamal Ayifimi and Armel Gouvoeke for their help in the field. Contributions from Fernand Sohindji are acknowledged.

Conflicts of Interest: The authors declare no conflicts of interest.

\section{References}

1. Ambrose-Oji, B. Urban Food Systems and African Indigenous Vegetables: Defining the Spaces and Places for African Indigenous Vegetables in Urban and Peri-Urban Agriculture Urban food systems and trends in vegetable production in urban. In African Indigenous Vegetables in Urban Agriculture; Routledge: London, UK, 2009; pp. 33-66.

2. Sogbohossou, E.D.; Achigan-Dako, E.G.; van Andel, T.; Schranz, M.E. Drivers of management of spider plant (Gynandropsis gynandra) across different socio-linguistic groups in Benin and Togo. Econ. Bot. 2018, 72, 411-435. [CrossRef]

3. Sogbohossou, O.E.; Achigan-Dako, E.G.; Komlan, F.A.; Ahanchede, A. Diversity and differential utilization of Amaranthus spp. along the urban-rural continuum of southern Benin. Econ. Bot. 2015, 69, 9-25. [CrossRef]

4. Yang, R.-Y.; Keding, G.B. Nutritional contributions of important African indigenous vegetables. In African Indigenous Vegetables in Urban Agriculture; Routledge: London, UK, 2009; pp. 137-176.

5. Guidi, L.; Landi, M. Aromatic plants: Use and nutraceutical properties. Novel Plant Bioresour. Appl. Food Med. Cosmet. 2014, 303-345. [CrossRef]

6. Vihotogbé, R.; Sossa-Vihotogbé, C.; Achigan-Dako, G. Safety of Botanical Ingredients in Personal Healthcare: Focus on Africa. Novel Plant Bioresour. Appl. Food Med. Cosmet. 2014, 28, 395-408.

7. Dansi, A.; Adjatin, A.; Adoukonou-Sagbadja, H.; Faladé, V.; Yedomonhan, H.; Odou, D.; Dossou, B. Traditional leafy vegetables and their use in the Benin Republic. Genet. Resour. Crop Evol. 2008, 55, 1239-1256. [CrossRef]

8. Segnon, A.C.; Achigan-Dako, E.G. Comparative analysis of diversity and utilization of edible plants in arid and semi-arid areas in Benin. J. Ethnobiol. Ethnomed. 2014, 10, 80. [CrossRef]

9. Achigan-Dako, E.G.; N’Danikou, S.; Assogba-Komlan, F.; Ambrose-Oji, B.; Ahanchede, A.; Pasquini, M.W. Diversity, geographical, and consumption patterns of traditional vegetables in sociolinguistic communities in Benin: Implications for domestication and utilization. Econ. Bot. 2011, 65, 129. [CrossRef]

10. Achigan-Dako, E.G.; Pasquini, M.W.; Assogba Komlan, F.; N'danikou, S.; Yédomonhan, H.; Dansi, A.; Ambrose-Oji, B. Traditional vegetables in Benin; Institut National des Recherches Agricoles du Bénin, Imprimeries du CENAP: Cotonou, Benin, 2010. 
11. Dansi, A.; Vodouhè, R.; Azokpota, P.; Yedomonhan, H.; Assogba, P.; Adjatin, A.; Loko, Y.; Dossou-Aminon, I.; Akpagana, K. Diversity of the neglected and underutilized crop species of importance in Benin. Sci. World J. 2012, 2012, 932947. [CrossRef]

12. N'Danikou, S.; Achigan-Dako, E.G.; Wong, J.L. Eliciting local values of wild edible plants in Southern Benin to identify priority species for conservation. Econ. Bot. 2011, 65, 381-395. [CrossRef]

13. Sanoussi, F.; Ahissou, H.; Dansi, M.; Hounkonnou, B.; Agre, P.; Dansi, A. Ethnobotanical investigation of three traditional leafy vegetables [Alternanthera sessilis (L.) DC. Bidens pilosa L. Launaea taraxacifolia Willd.] widely consumed in southern and central Benin. J. Biodivers. Environ. Sci. 2015, 6, 187-198.

14. Eyssartier, C.; Ladio, A.H.; Lozada, M. Cultural transmission of traditional knowledge in two populations of north-western Patagonia. J. Ethnobiol. Ethnomed. 2008, 4, 25. [CrossRef]

15. Lozada, M.; Ladio, A.; Weigandt, M. Cultural transmission of ethnobotanical knowledge in a rural community of northwestern Patagonia, Argentina. Econ. Bot. 2006, 60, 374-385. [CrossRef]

16. Voeks, R.A. Disturbance pharmacopoeias: Medicine and myth from the humid tropics. Ann. Assoc. Am. Geogr. 2004, 94, 868-888.

17. Voeks, R.A. Are women reservoirs of traditional plant knowledge? Gender, ethnobotany and globalization in northeast Brazil. Singap. J. Trop. Geogr. 2007, 28, 7-20. [CrossRef]

18. Ruddle, K. The transmission of traditional ecological knowledge. In Traditional Ecological Knowledge: Concepts and Cases; Canadian Museum of Nature and IDRC: Ottawa, ON, Canada, 1993; pp. 17-31.

19. Boesch, C.; Tomasello, M. Chimpanzee and Human Cultures. Curr. Anthropol. 1998, 39, 591-604.

20. Aunger, R. The life history of culture learning in a face-to-face society. Ethos 2000, 28, 445-481. [CrossRef]

21. Guimbo, I.D.; Mueller, J.G.; Larwanou, M. Ethnobotanical knowledge of men, women and children in rural Niger: A mixed-methods approach. Ethnobot. Res. Appl. 2011, 9, 235-242. [CrossRef]

22. Souto, T.; Ticktin, T. Understanding interrelationships among predictors (age, gender, and origin) of local ecological knowledge. Econ. Bot. 2012, 66, 149-164. [CrossRef]

23. Lykke, A.; Kristensen, M.; Ganaba, S. Valuation of local use and dynamics of 56 woody species in the Sahel. Biodivers. Conserv. 2004, 13, 1961-1990. [CrossRef]

24. Gaoue, O.G.; Coe, M.A.; Bond, M.; Hart, G.; Seyler, B.C.; McMillen, H. Theories and major hypotheses in ethnobotany. Econ. Bot. 2017, 71, 269-287. [CrossRef]

25. Avohou, H.T.; Vodouhe, R.S.; Dansi, A.; Kpeki, B.; Bellon, M. Ethnobotanical factors influencing the use and management of wild edible plants in agricultural environments in Benin. Ethnobot. Res. Appl. 2012, 10, 571-592.

26. Denton, O.A. Crassocephalum crepidioides (Benth.) S. Moore. In Plant Ressources of Tropical Africa 2: Vegetables; Grubben, G.J.H., Denton, O.A., Messiaen, C.-M., Schippers, R.R., Lemmens, R.H.M.J., Oyen, L.P.A., Eds.; PROTA Foundation: Wageningen, The Netherlands; Backhuys Publishers: Leiden, The Netherlands; CTA: Wageningen, The Netherlands, 2014.

27. Stadlmayr, B.; Charrondiere, U.R.; Addy, P.; Samb, B.; Enujiugha, V.N.; Bayili, R.G.; Fagbohoun, E.G.; Smith, I.F.; Thiam, I.; Burlingame, B. Composition of selected foods from West Africa; Food and Agriculture Organization: Rome, Italy, 2010; pp. 13-14.

28. Adebisi, A. Launaea Taraxacifolia (Willd) Amin ex C Jeffrey \{Internet $\}$ Record from Protabase. In PROTA (Plant Resources of Tropical Africa/Ressources Vegetales de l'Afrique Tropicale); Grubben, G.J.H., Denton, O.A., Eds.; PROTA Foundation: Wageningen, The Netherlands; Backhuys Publishers: Leiden, The Netherlands; CTA: Wageningen, The Netherlands, 2004.

29. Fomum, F.U. Vernonia amygdalina Delile. In Plant Ressources of Tropical Africa 2: Vegetables; Grubben, G.J.H., Messiaen, C.-M., Schippers, R.R., Lemmens, R.H.M.J., Oyen, L.P.A., Eds.; PROTA Foundation: Wageningen, The Netherlands; Backhuys Publishers: Leiden, The Netherlands; CTA: Wageningen, The Netherlands, 2004; pp. 543-546.

30. Akoègninou, A.; Van der Burg, W.; Van der Maesen, L.J.G. Flore analytique du Bénin; Backhuys Publishers: Wageningen, The Netherlands, 2006.

31. Économique, I.N.D.L.S.E.D.L.A.; International, I. Enquête Démographique et de Santé du Bénin 2011-2012: Rapport de synthèse; INSAE et ICF International Calverton: Calverton, MD, USA, 2013.

32. CENALA. Atlas et études Sociolinguistiques du Bénin; Agence Intergouvernementale de la Francophonie: Cotonou, Benin, 2003. 
33. Sogbohossou, E.D.; Achigan-Dako, E.G.; Maundu, P.; Solberg, S.; Deguenon, E.M.; Mumm, R.H.; Hale, I.; Van Deynze, A.; Schranz, M.E. A roadmap for breeding orphan leafy vegetable species: A case study of Gynandropsis gynandra (Cleomaceae). Hortic. Res. 2018, 5, 1-15. [CrossRef]

34. Etongo, D.; Djenontin, I.N.S.; Kanninen, M.; Glover, E.K. Assessing use-values and relative importance of trees for livelihood values and their potentials for environmental protection in Southern Burkina Faso. Environ. Dev. Sustain. 2017, 19, 1141-1166. [CrossRef]

35. Gomez-Beloz, A. Plant use knowledge of the Winikina Warao: The case for questionnaires in ethnobotany. Econ. Bot. 2002, 56, 231-241. [CrossRef]

36. Friedman, J.; Yaniv, Z.; Dafni, A.; Palewitch, D. A preliminary classification of the healing potential of medicinal plants, based on a rational analysis of an ethnopharmacological field survey among Bedouins in the Negev Desert, Israel. J. Ethnopharmacol. 1986, 16, 275-287. [CrossRef]

37. R Core Team, P. R: A Language and Environment for Statistical Computing [Computer Software Manual]; R Core Team, R Foundation for Statistical Computing: Vienna, Austria, 2016.

38. De Albuquerque, U.P. Re-examining hypotheses concerning the use and knowledge of medicinal plants: A study in the Caatinga vegetation of NE Brazil. J. Ethnobiol. Ethnomed. 2006, 2, 30. [CrossRef]

39. Adjatin, A.; Dansi, A.; Eze, C.; Assogba, P.; Dossou-Aminon, I.; Akpagana, K.; Akoègninou, A.; Sanni, A. Ethnobotanical investigation and diversity of Gbolo (Crassocephalum rubens (Juss. ex Jacq.) S. Moore and Crassocephalum crepidioides (Benth.) S. Moore), a traditional leafy vegetable under domestication in Benin. Genet. Resour. Crop Evol. 2012, 59, 1867-1881. [CrossRef]

40. Dairo, F.; Adanlawo, I. Nutritional quality of Crassocephalum crepidioides and Senecio biafrae. Pak. J. Nutr. 2007, 6, 35-39.

41. Hanazaki, N.; Herbst, D.F.; Marques, M.S.; Vandebroek, I. Evidence of the shifting baseline syndrome in ethnobotanical research. J. Ethnobiol. Ethnomed. 2013, 9, 75. [CrossRef]

42. Begossi, A.; Hanazaki, N.; Tamashiro, J.Y. Medicinal plants in the Atlantic Forest (Brazil): Knowledge, use, and conservation. Hum. Ecol. 2002, 30, 281-299. [CrossRef]

43. Dovie, D.B.; Witkowski, E.; Shackleton, C.M. Knowledge of plant resource use based on location, gender and generation. Appl. Geogr. 2008, 28, 311-322. [CrossRef]

44. Adjatin, A.; Dansi, A.; Badoussi, E.; Sanoussi, A.; Dansi, M.; Azokpota, P.; Ahissou, H.; Akouegninou, A.; Akpagana, K.; Sanni, A. Proximate, mineral and vitamin C composition of vegetable Gbolo [Crassocephalum rubens (Juss. ex Jacq.) S. Moore and C. crepidioides (Benth.) S. Moore] in Benin. Int. J. Biol. Chem. Sci. 2013, 7, 319-331. [CrossRef]

45. Arawande, J.O.; Amoo, I.A.; Lajide, L. Chemical and phytochemical composition of wild lettuce (Launaea taraxacifolia). J. Appl. Phytotechnol. Environ. Sanit. 2013, 2, 25-30.

46. Reyes-García, V.; Broesch, J.; Calvet-Mir, L.; Fuentes-Peláez, N.; McDade, T.W.; Parsa, S.; Tanner, S.; Huanca, T.; Leonard, W.R.; Martínez-Rodríguez, M.R. Cultural transmission of ethnobotanical knowledge and skills: An empirical analysis from an Amerindian society. Evol. Hum. Behav. 2009, 30, 274-285. [CrossRef]

47. Codjia, J.T.C.; Vihotogbe, R.; Lougbegnon, T. Phytodiversité des légumes-feuilles locales consommées par les peuples Holli et Nagot de la région de Pobè au sud-est du Bénin. Int. J. Biol. Chem. Sci. 2009, 3. [CrossRef]

(C) 2019 by the authors. Licensee MDPI, Basel, Switzerland. This article is an open access article distributed under the terms and conditions of the Creative Commons Attribution (CC BY) license (http://creativecommons.org/licenses/by/4.0/). 